\title{
Present status of broodstock management at carp hatcheries in Jessore
}

\author{
M. A. Samad ${ }^{1 *}$, M. T. Hossain ${ }^{1}$ and B. M. S. Rahman ${ }^{2}$ \\ ${ }^{1}$ Fisheries and Marine Bioscience Department, Jessore Science and Technology University, Jessore, Bangladesh \\ and ${ }^{2}$ Riverine Station, Bangladesh Fisheries Research Institute, Chandpur, Bangladesh, *E-mail: \\ abdussamadjstu@gmail.com
}

\begin{abstract}
This study represented a survey report on present status of management of carp brood fish. The survey was conducted with 40 hatcheries at Chacrha in Jessore from June to November, 2012. Production of brood fish was found to depend on the combined interaction between feed and culture technique. Some information showed that brood fish selection for induced breeding was done on the basis of their experience. Pond preparation was carried out properly but stocking density of brood fish was quite high and water quality was not maintained properly. Negative selection of brood fish was done in few hatcheries aiming at reducing the cost for collecting or purchasing good quality broods. The sources of brood fish were mainly own and other sources were Halda River, Padma River, Govertment brood bank and World Fish Center. Feed used for brood carp fish were mainly rice bran (34.57\%), mustard oil cake (21.78\%), vitamin and mineral premix (0.8\%), wheat flour (8.64\%), fish meal (8.64\%) and soya bean flour (10.37\%), maize flour (6.91\%), rice ( 6.91\%), di-calcium (1.73\%), salt (0.34\%) and antioxidant (0.04\%) . Nutritional composition of feed was mainly crude protein (30-40\%), crude lipid (10-12\%), carbohydrate (20-30\%). Protein percentage of feed always tried to keep $26 \%$ even though it was varied due to the other feed ingredients. Fertilizer such as Triple super phosphate $(0.73 \mathrm{~kg} / \mathrm{dec})$, urea $(0.25 \mathrm{~kg} / \mathrm{dec})$, potash $(1.5 \mathrm{~kg} / \mathrm{decl})$, cowdung (5.19 $\mathrm{kg} / \mathrm{dec})$, poultry offal $(1.9 \mathrm{~kg} / \mathrm{dec})$ and Murite of potash $(0.13 \mathrm{~kg} / \mathrm{dec})$ were used. Scientific brood and hatchery management could be a good approach to attain the main purpose of aquaculture.
\end{abstract}

Keywords: Brood carp, Hatchery, Management, Production, Jessore

\section{Introduction}

The steadily growing importance of fish farming has compelled improvements in the technologies necessary for securing the initial and basic requirements for productive aquaculture; namely the production of fish seed for stocking. Fish culture today is hardly possible without the artificial propagation of fish seeds of preferred cultivable fish species. The need for the production of quality fish seed for stocking the fish ponds and natural water bodies has indeed increased steadily (Brain and Army, 1980).

Global increases in consumption of food fish will take place largely in the developing countries, where population is growing and higher incomes are allowing purchase of high valued fisheries products. However, fish production in under developed countries where fish protein is needed to prevent malnutrition is a key element of food security in these regions and a critical area where innovative programs are needed to increase production. According to the Food and Agriculture Organization, aquaculture is growing more rapidly than all other animal food-production sectors (Siriwardena, 2007). Fish and fisheries sectors have contributed $4.43 \%$ of total GDP and it has exerted $2.73 \%$ of total export earnings in the fiscal year of 2010-2011 in Bangladesh (DoF, 2012). It has created an opportunity of full time employment of 5.4 million people and per time of nearly 15.6 million people (DoF, 2012).

Historically fish farming has been a part time activity of peasant farmer who develop it as an efficient means of utilizing farm resource to the maximum extend. Carp culture introduced in Bangladesh in 1926 (Nazmul, 2000). Indian major carps, some exotic carps and catfishes are the main cultured species for the closed water system and production of these species completely depends on timely and adequate supply of quality seed. Until very recent times, carp culture in pond remain the main stay of aquaculture whole of the world including Bangladesh however, a number of other fish have been added to the species combinations with the expectation of increasing productivity in polyculture pond (Pillay, 1993). Brood fish is considered as the heart of the hatchery and management of brood stock is the key of quality seed 
production. Success of induced breeding depends on availability of sufficient number of brood fish. Therefore broodstock should be maintained scientifically so that ripe broods could be obtained during the whole breeding season. Most of the government hatcheries have own broodstock and around 25 percent recruitments take place in every year. On the other hand, few private hatcheries have their own stock and maintain them more or less scientifically but there are many private hatcheries that do not have the required number of broods. During breeding season they instantly buy broods from others and produce fry from them to fulfill their target (Sarder, 2002).

Over the last two decades, Jessore district of Bangladesh has experienced an intense growth of fish breeding industries. The success of hatchery mainly depends on quality broods rearing techniques, pond management, including liming, fertilization and feeding and water quality management. The ultimate goals of hatchery owners of Chanchra area are to provide quality fish fry to the fish farmers as their needs create employment facilities and improve socio-economic condition. In the present study efforts were made to survey overall brood fish management practices as followed in Indian major carps brood rearing in Jessore. The study was based on questionnaire survey and interview of the hatchery owners. The study was conducted with focusing on the characteristic brood carp fish management practices involving sources of brood, liming, feeding and fertilization in this region that experienced a rapid growth and development of the seed production industry. The overall objective of the study was to know the present brood carp fish management scenario of the hatchery under the present study.

\section{Materials and Methods}

The methodology of the study was adopted for selection of the study area and collections of data are described below.

\section{Study area}

The study was conducted during June to November, 2012. A total of 40 private hatcheries having about 200 ponds in Jessore district were brought under survey. As this area has experienced a boom in Indian major carps' hatchery and seed production industries, Jessore was selected for the study site. Chachra at Jessore Sadar Upazilla was taken as the main study area.

\section{Questionnaire preparation}

The questionnaire was prepared emphasizing on the objective mentioned above. Before finalization of the questionnaire, it was pre-tested through a field visit. Then the questionnaire was finalized and prepared for survey work. The questions were specific and free from any kind of influence.

\section{Data collection}

Data were collected through a structured questionnaire. After finalizing the questionnaire, relevant data were collected by interviewing the hatchery owners and the farmers directly. In order to minimize errors, data were collected in local units. These were subsequently converted into appropriate units.

\section{Secondary data collection}

The existing data related to this study were collected from Freshwater substation, Bangladesh Fisheries Research Institute (BFRI), Jessore; Department of Fisheries (DoF); BRAC and others Government and Non-government organization, different books, journals and websites.

\section{Data analysis}

All the collected information obtained from different carp hatcheries were accumulated and analyzed. Microsoft word, Microsoft excel etc were used to interpret the data. 


\section{Results and Discussion}

\section{Physical condition of pond}

Physical condition of pond included area of pond, shape, water depth, water color etc. and these were described below.

Area of pond: Field survey showed that the areas of pond of different hatchery of Chanchra were varied from 33.33 to $400 \mathrm{dec}$. According to area and shape, ponds were grouped as given in Table 1.

Table 1. Ponds according to area

\begin{tabular}{|c|c|}
\hline Area (Decimal) & No. of pond \\
\hline$<42$ & 38 \\
\hline $42-84$ & 36 \\
\hline $84-126$ & 58 \\
\hline $126-168$ & 24 \\
\hline $168-210$ & 14 \\
\hline $210-252$ & 12 \\
\hline $252-294$ & 8 \\
\hline $294-336$ & 6 \\
\hline$>336$ & 4 \\
\hline Total & 200 \\
\hline
\end{tabular}

\section{Pond preparation}

Pond management plans of the hatchery were done dividing into pre-stocking management, management during culture, post-stocking management. These were done according to the needs and available low cost facilities of the culture system. The steps of pond preparation were described below.

Drying: Most of the ponds retained water round the year but some ponds were completely dewatered by pumping and allowed to dry by sunlight. Drying out before stocking and dried varied from 7-10 days. Fig. 2 shows the dryness condition of studied ponds.

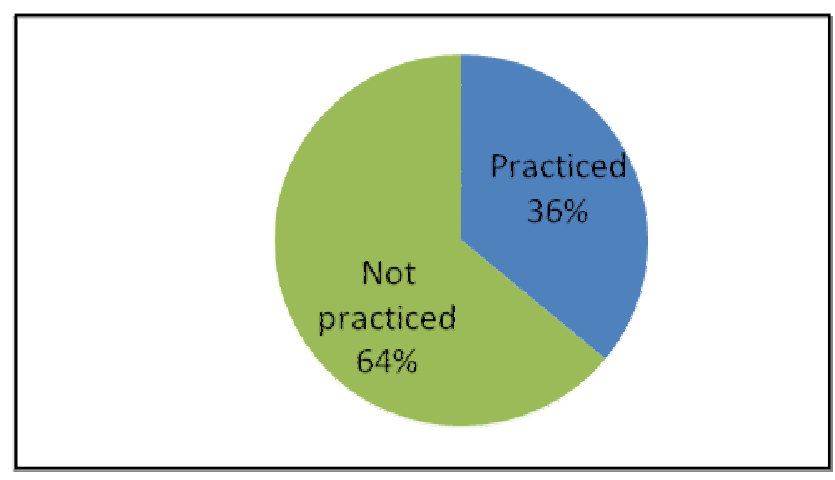

Fig. 1. Dryness condition of ponds

Most of the brood ponds was not possible to dewater because during the off season of hatchery operation specially, in winter season, ponds contained huge amount of water mass which was expensive to dewater. So the hatchery owners took alternative measures to prepare the pond for brood culture. 
Water source and color: Underground water was the main source of water for all hatcheries under the present study. As underground water contained significant level of iron, there was likely a reproductive problem where iron creating a layer on eggs of fish. According to Bryan and Alabaster (1976a \& 1980) the sub lethal toxicity of iron may be in the form of change in morphology, histology, growth, development, swimming performance, respiration, blood chemistry, enzyme activity, reproduction, endocrinology, reproduction and behavioral changes. The higher concentration of iron in fish habitat may create a layer on fish gill that leads fishes in cardiovascular disease, heart disease, respiratory problems, making susceptible to microbes etc. Goel (1997) stated that the chlorinated pesticide such as DDT, endrin, dieldrin are sparingly soluble in water but show solubility in oils, fats that makes fishes them highly bioaccumulative. So fish as well as all other aquatic plants and animals were susceptible to concentration of toxic heavy metals. The reasons of the unavailability or scarcity of underground water in the present study area during the hatchery operation in off- peak season was going down the underground water layer.

Table 2. Numbers of ponds according to watercolor and production

\begin{tabular}{|c|c|}
\hline Water color & No. of pond \\
\hline Green & 165 \\
\hline Gray & 28 \\
\hline Transparent & 7 \\
\hline Total & 200 \\
\hline
\end{tabular}

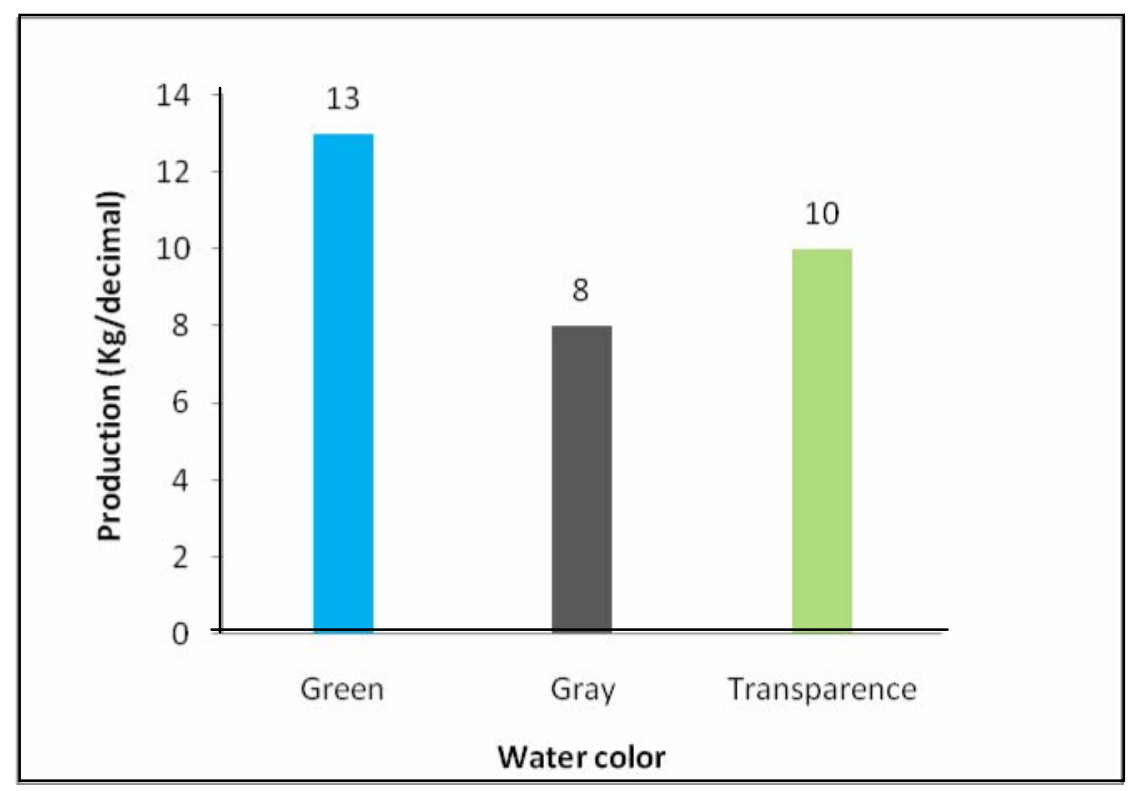

Fig. 2. Production according to water color

Water color of 165 ponds was green while 28 were gray and seven were transparent. Sometimes turbidity occurred after fishing by nets but it stayed just for few minutes and did not affect fish production. Water of pond had high light penetrating capacity. Ponds were grouped according to water color given in Table 2. Water color of brood culture pond in different region of Bangladesh varied from light green to gray except few ponds which was black and turbid (Das, 1993), which has similar with this study.

Liming: Though the rate of liming was depended upon $\mathrm{pH}$ of the pond water, most of the farmers are not aware of it. They usually spreaded lime over the pond bottom 5-6 times in a year. Rate of liming varied from hatcheries to hatcheries. Some farmers used lime during drying however others during culture period when they considered. Generally the farmers used lime during culture period when water quality 
deteriorated. The doses were found to be ranged from 500- $1200 \mathrm{gm} \mathrm{dec}-1$ in the present study. Farmers mostly applied lime at the time of drying the pond. They also did spray diluted calcium carbonate on the surface of pond water during rearing when the water quality got deteriorated, however the dose used was always lower than the dose used in pond preparation.

Table 3. Production of fish at different liming rate during culture period in different hatcheries

\begin{tabular}{|c|c|}
\hline Amount (kg/decimal) & No. of pond \\
\hline $0.5-0.6$ & 20 \\
\hline $0.6-0.7$ & 22 \\
\hline $0.7-0.8$ & 42 \\
\hline $0.8-0.9$ & 56 \\
\hline $1-1.2$ & 60 \\
\hline Total & 200 \\
\hline
\end{tabular}

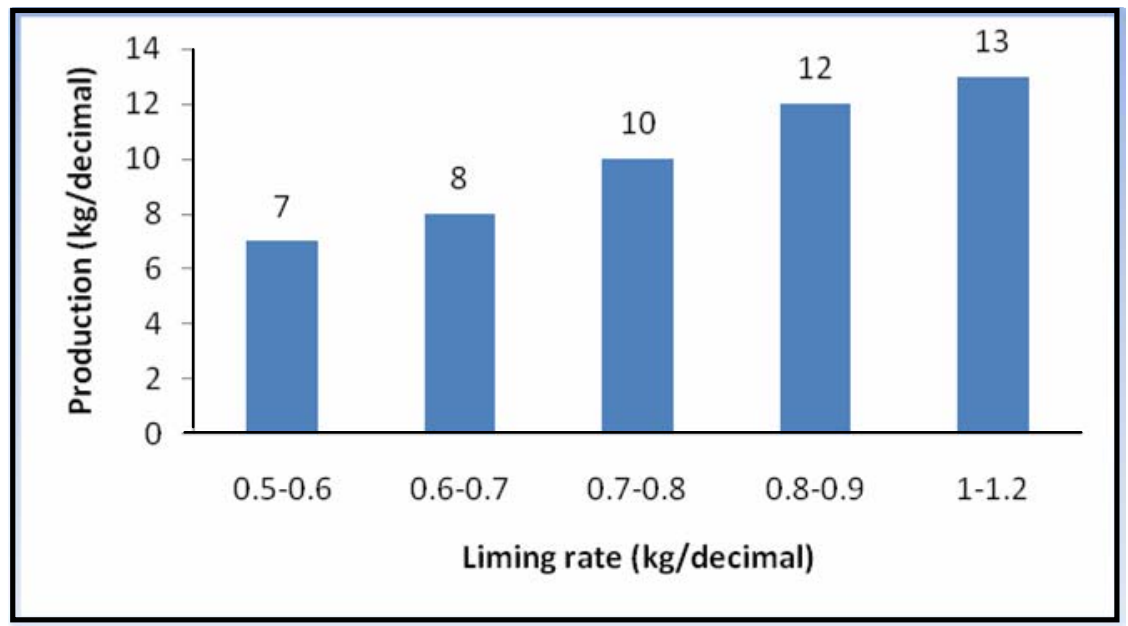

Fig. 3. Production of fish at different liming rates

Liming was normally done at a rate of $1000 \mathrm{~g} \mathrm{dec}^{-1}$ (Haque, 1991 and Mazid, 1992). Chakraborty (1979) reported liming dose at 600-1200 $\mathrm{g} \mathrm{dec}^{-1}$ in India. Shaha and shah (2010) reported that liming rate ranged from 500-700 $\mathrm{gec}^{-1}$ and 600-800 $\mathrm{gec}^{-1}$ in Jessore and Mymensingh regions respectively. All the above results are similar to this study that found majority of the ponds required $0.8-1.2 \mathrm{~kg} \mathrm{dec}^{-1}$.

Fertilization: Most of the farmers used fertilizer before stocking of fish and during culture period whenever they thought necessary. The differences in the rate of fertilizer application in this region was ascertained to be based on the species combination, soil fertility, water quality and on the farmers' own experience on culture practices. Most of the farmers were seen using fertilizers at near optimum rates, only a few used at very low levels. Application rate of fertilizers differed from hatchery to hatchery. Every time TSP and oil cake were soaked in water a night before application.

The application rate of fertilization differ from region to region (Islam et al., 2002). Shaha and Shah (2010) reported that in general, the amount of the fertilizers applied by the farmers in Jessore region was higher than those applied in Mymensingh region and this was ascribed to the differences in soil and water quality; quality of soil and water of Jessore was not as good as in Mymensingh region. So the result of the present study is supported by the result shown by Shaha and Shah (2010).

Source of brood: Preferably big size, healthy, good looking and matured males and females should be collected from the natural sources (rivers, lakes, and reservoirs) as brood stock. Brood collected from culture ponds might be of the same sized, matured and healthy. For the exotic species, the culture ponds were the only source of brood stock. Collected broods should be transferred into the brood stocking pond with aeration or with the facilities for water exchange in the month of October to December (Kumar, 1992). 


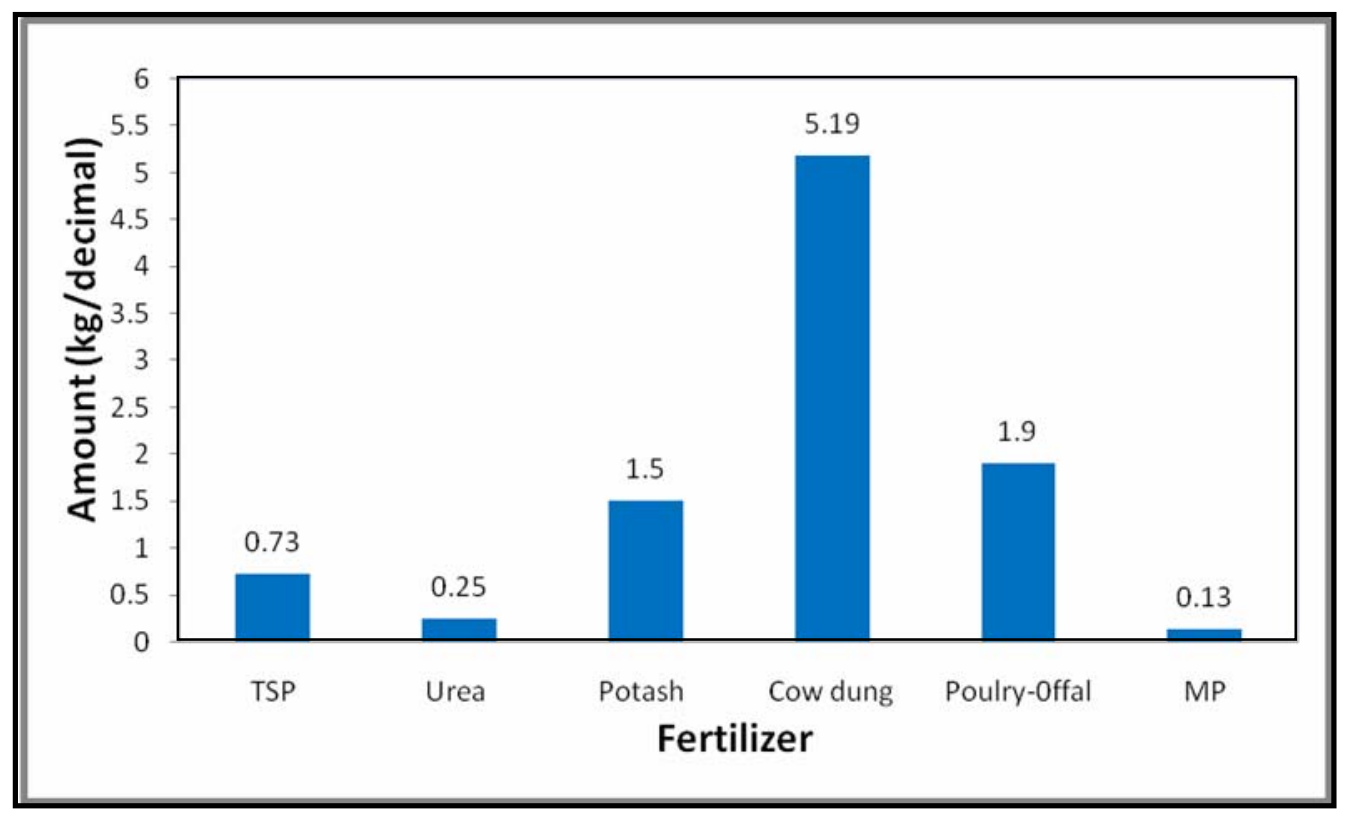

Fig. 4. Application of fertilizers (kg/decimal)

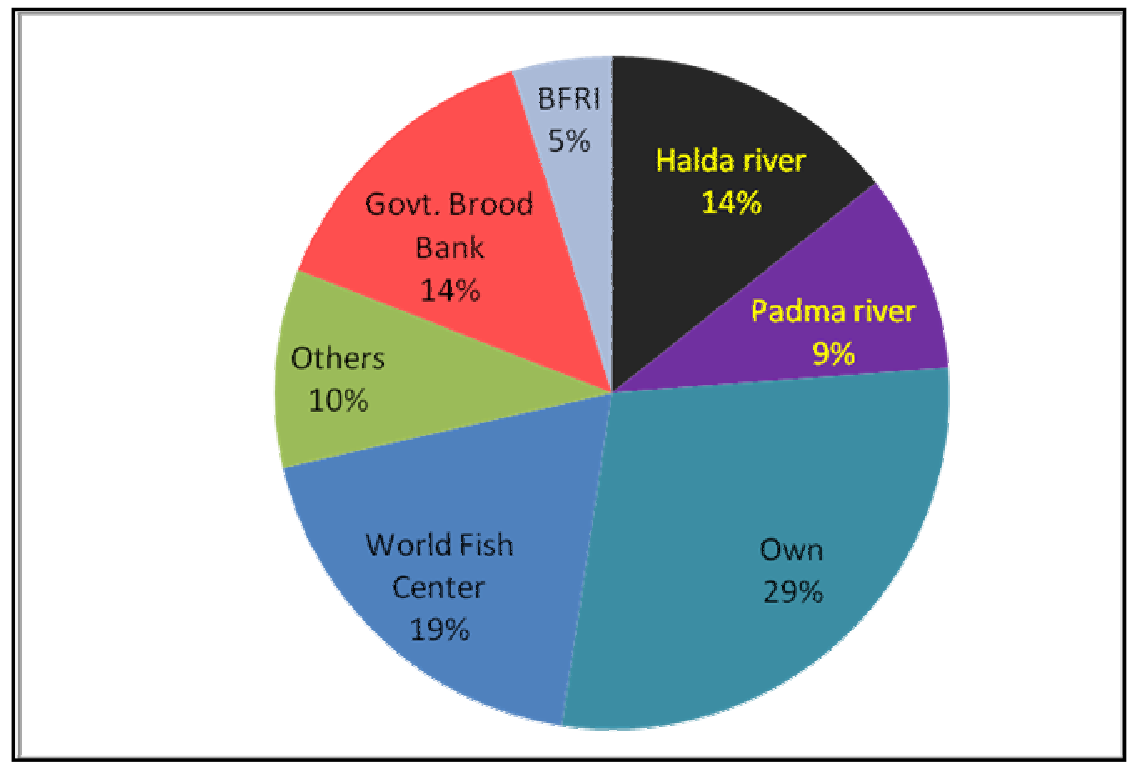

Fig. 5. Sources of brood fish

Some hatcheries (29\%) reared their own brood in their leased brood cultured pond and usually they use neither brood stock from natural sources nor exchange breeders among farms. Each hatchery therefore can be considered as an isolated, self-sustaining and genetically closed unit (Eknath and Doyle, 1990). Most of the hatchery have own and external sources of brood (World Fish Center, BFRI, Halda River, Padma River, Govt. Brood Bank). Recently World fish center, Bangladesh is providing brood carps of natural sources without cost to the hatchery owners under the project naming "Feed the Future". The World Fish Center collect brood fish from different natural sources such as Halda, Padma, Ganga river etc. then stock the brood and distribute them among the fish hatchery owners. The main sources were World Fish Center, BFRI, Halda River, Padma River and Govt. Brood Bank. The percentage of sources of brood is given in Figure 5. Before 1970s the total fish production in our country mostly depends on natural 
water bodies such as rivers, floodplains, haors, baors, beels etc. but recently Hatcheries have played a significant contribution to meet the fish seed demand of the present. So they have to use their own produced brood for breeding purpose due to unavailability and cost of wild brood fish (DoF, 2010). From the beginning the natural sources of rivers such as Padma River, Halda River, Ganga River, Jamuna River etc were the major source of brood carp and carp seed in Bangladesh. Millions of eggs and spawn fish were collected from the rivers during monsoon from May to August every year. (DoF, 2012). In 1984 the spawn production in Bangladesh was estimated to be $23657 \mathrm{~kg}$ from Padma-Brahmaputra river system, $895 \mathrm{~kg}$ from Halda River and $625 \mathrm{~kg}$ from all hatcheries. Tasi and Ali (1997) noted that construction of Farakka dam and other embankments, sedimentation of rivers and over exploitation from the natural stock are the major factors for the decline of major carps in stocks in the River systems of Bangladesh. With the declining of the fish production from capture fishery and increasing the demand of fish for human consumption, aquaculture venture has been emerged as a most vital wing of aquaculture. Therefore, it has been realized that intensification of aquaculture could be the most effective means of increasing fish production to meet the shortage requirement of animal protein.

\section{Brood collection and management}

Selection of brood: The broods were selected on the basis of their body color, size and swimming activities. The weight brood carp fish (minor carp; Pantius sarana to major carp; Catla catla) were varied from $700 \mathrm{gm}$ to $8 \mathrm{~kg}$. Frequently the hatchery operators used their own produced small sized broods for breeding purposes because of unavailability and high cost of healthy, natural perfect quality of brood fish in peak season.

Preferably 1 to 3 years weighing about $3.5 \mathrm{~kg}$ to $8 \mathrm{~kg}$ old mature males and females should be collected from the natural sources (rivers, lakes, and reservoirs) as broodstock. (sarder et al., 2002).

Stocking time: Generally the stocking of fry varies from April to September. The fries those hatched from fertilized eggs tried to sell all of them by farmers. Fry selling continues from May to September. Then the unsold fry were stocked in their nursery and then subsequently rearing pond acquired through leasing system to produce brood fish. They never follow stocking rate of carp given by fisheries specialist. The fry which is likely to be made brood were identified at first and keep them separate from other fry. The peak season of fry selling is May to June. Grower fish season continued from mid September to March. Stocking time of fish in India begins al last of March to September, farmer also stock fish all around the year but their size is comparatively big (Alikunhi and Sukumaran, 1971), that is similar to this study

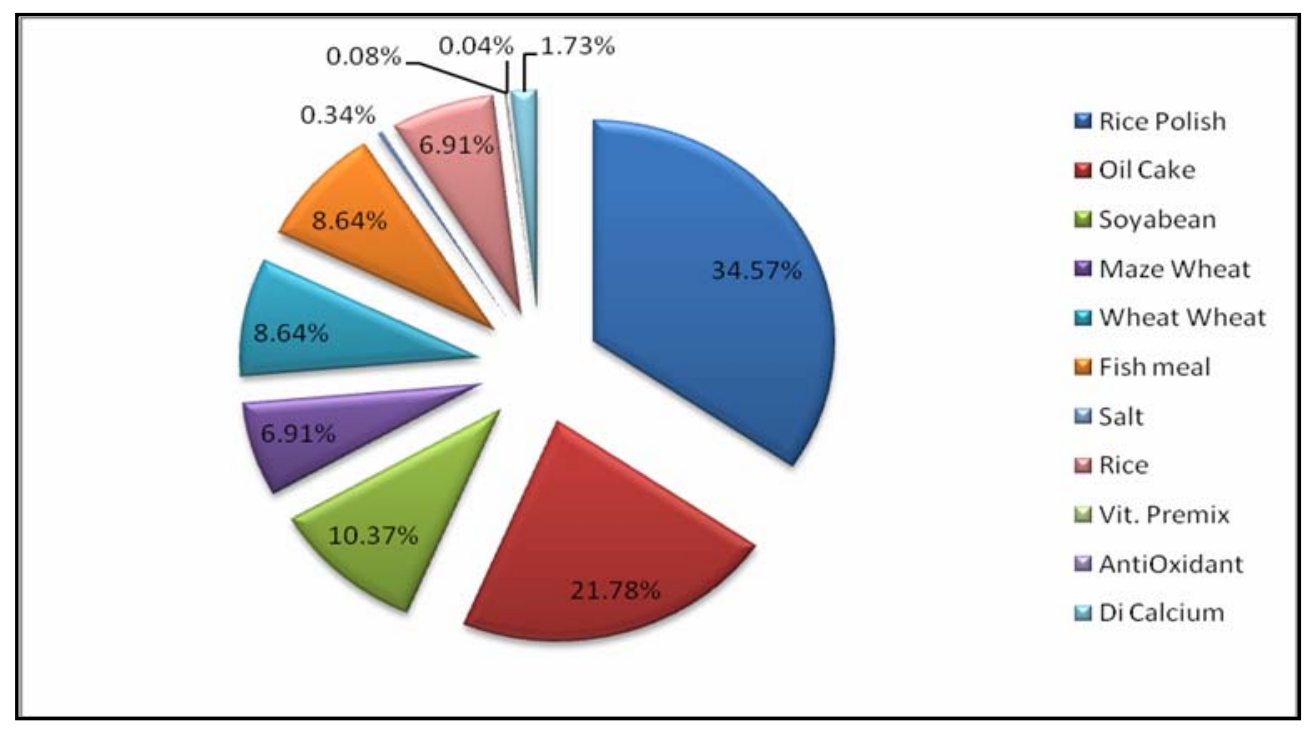

Fig. 6. Food ingredients $\left(\mathrm{gm} \mathrm{dec}^{-1}\right)$ used in brood ponds in Jessore 
Food ingredients used in brood ponds in the study area: The feeding of brood fish was done with farm made feeds at different private hatchery owned brood ponds under the present study. In the present study area the most common type ingredients were consisted of varied food items ranging from maize, molasses, course flour, cooked rice, egg yolk, meat bone, chicken liter, di-calcium phosphate and salt etc. The proportion of the items in the feed was not in fixed scale and depended on the experience of the individual hatchery owners.

They did not have strict idea as to the protein and lipid content of the feed either and claimed for $25-30 \%$ protein on assumption. Protein and lipid requirement for warm water omnivorous species were given by FAO, (1983); the Indian major carps and grass carp require $30 \%$ protein and $6 \%$ lipid. Feeds were applied both in dough and pellet forms. In case of preparation, feeds were soaked in a concrete pit, a night before. Then the soaked feed materials were made into dough with dry fish meal and thrown into a definite point of the pond. The dry ingredients were mixed with soaked oil cake and molasses and extruded into pellets. The pellets were dried in sun before application. In dough feeding, the feed ingredients got suspension in water so that the unused feed would have fertilizers effect to water. Haque (1991) and Islam et al. (2002) suggest the use of similar composition and proportions for brood was shown in Figure 6 of Indian major carps in Bangladesh. The rate and frequency of feeding of brood fish in the region were found variable. The fishes were fed at $3-4 \%$ of body weight, $5-6$ days in a week. The feeding rate was followed in the initial stage of brood preparation, however, as the breeding season approached, the rate was decreased to $1-1.5 \%$ of body weight, 3-4 times per week. The feeding rates were found to depend on species combination. Brood pond management relating to fertilization and feeding was the prime consideration for producing quality broods and that in turn allowed the availability and quality seed for successful aquaculture in the country. The feeding practices followed in the region were broadly similar however; there were some variations in the rates of ingredients of both fertilizer and feed. The differences in the practices were ascribed to the differences in soil and water quality, species combination and individual farmer's experience.

\section{Determination of sex and gonadal maturation}

The hatchery owner or the hatchery technician separated the male and female fish by their long time experience based on the morphometric characters of each individual. They identify male and female fish by means of their pectoral fins size of the abdominal part of body. They sorted out the mature male brood by means of gentle pressure along the abdominal portion to eject milky white milt and female brood by looking at pinkish genital papilla. Then they selected fish for spawning.

Sex of breeders was determined by means of their pectoral fins. A mature male broodstock had rough pectoral fins due to the presence of "ctenoid teeth structures" which appeared prominently along the first ray. A male brood was selected for induced spawning when it readily gave off milky white milt upon gentle pressure along the abdominal portion. A female breeder has smooth pectoral fins. When fully mature, its belly was distended with pinkish genital papilla. Gonadal maturity was assessed by cannulation. Stage IV mature eggs are yellowish in color, easily dispersed in freshwater, and are 1.0-1.4 mm diameter. The nuclei of mature eggs were polarized when placed in a petri dish containing FAA solution (9.05\% formaldehyde, $4.55 \%$ acetic acid, and $86.4 \%$ ethyl alcohol) (Fermin, 1986a).

\section{Injection of hormone}

The hypothalamus in vertebrates contained certain neuron secretary cells specialized for the production of hormones. In many cases neurons secreted a hormone for synaptic transmission (Fagbenro et al., 1991). The mediator between the environment and the animal that was, the nervous system and especially by the hypothalamus, was in close proximity to the pituitary. This was described as the "master gland", and was situated below the fore brain. It was stimulated directly by external environmental change. The working of the pituitary is also related to the hypothalamus, which integrated so many of the visceral activities (Hogendoorn, 1981). Pituitary Gland (PG) hormone was commonly used in different hatcheries in Jessore. In case of female major carp, a preliminary dose of $0.5-0.6 \mathrm{mg}$ gland $1 \mathrm{~kg}$ body 
weight was injected after $5-6$ hours, a second dose of $1-1.5 \mathrm{mg} / 1 \mathrm{~kg}$ body weight was injected. The first dose was called primer dose and second dose was called booster. The male, on the other hand, received a single dose of $0.5-1.0 \mathrm{mg}$ gland/ $\mathrm{kg}$ body weight at the time of application of second injection to the female.

In case of Chinese carp first dose of 1-2 $\mathrm{mg} \mathrm{PG/kg} \mathrm{body} \mathrm{weight} \mathrm{was} \mathrm{administrated} \mathrm{to} \mathrm{the} \mathrm{female} \mathrm{followed}$ by $2-3 \mathrm{mg} \mathrm{PG/} \mathrm{kg}$ body weight was injected as second dose by maintaining 6 hours interval between two injections. Time interval between two injections was 6 hours. However the male Chinese carp received 2$3 \mathrm{mg} \mathrm{PG} / \mathrm{kg}$ body weight at a time of second injection to the female. The usual practice for hormone injection in case of Common carps, the first dose of $0.5 \mathrm{mg} \mathrm{PG} / \mathrm{kg}$ body weight was administrated to the female followed by $0.8 \mathrm{mg} P G / \mathrm{kg}$ body weight was injected as second dose by maintaining 6 hours interval between two injections. Time interval between two injections was 6 hours. The injected males and females were kept in separate tank. As indicated earlier, the time taken for the eggs to ripen for spawning or stripping depended on the water temperature. Generally, after 12 hours of first dose the stripping was occurred. First, the female was stripped by gently squeezing the abdomen towards the tail and the eggs that flow easily were collected in bowls or basin. Then the males were similarly stripped for milt, which was spreaded over the eggs in the same container and the contents were mixed immediately with a feather or a plastic sponge.

\section{Conclusion}

Carp brood management is the prime consideration for producing quality broods as well as quality seed for successful aquaculture in the country. Jessore is the most important region which has got recognition as the most promising areas for hatchery technology of Indian major carps. Thus it is important to get an idea about the practices of brood rearing relating to pond fertilization and feeding of broods. As Bangladesh is highly dense populated country in the third world, they can only be met their protein requirement through aquaculture. To fulfill this requirement, fish farmers have to be ensured with good quality seed through production of quality broods. Government should give loan to hatchery owners for continuous operation of hatchery as well as establish brood bank in Jessore. Brood and hatchery management in scientific way can ensure good quality fish seed and meet the main purposes of aquaculture.

\section{References}

Alabaster, J.S. and Lloyd, R. 1980. Water quality criteria for fresh water fish, Butterworths, London.

Ali, M.Y.1997. Induced breeding of major carps in ponds by pituitary hormone injection. Agriculture information service, Dhaka, Bangladesh.

Alikunhi, K.H., Skumaran, K.K. and Parameswaran, S. (1971). Studies on composite fish culture production by compatible combinations of Indian and Chinese carps. J. Ind. Fish. Assoc., 1 (1):26-57.

Brain, F.D. and C. Army, 1980. Induced fish breeding inSouth East Asia. Repot of the workshop held in Singapore, 25-26 November, 10RC-178e.

Bryan, G.W. 1976. Heavy metal contamination in the sea. In: ( R. Johnson, ed.) Marine pollution, Academic press, London. pp. 185302.

Chakrabarty, R.D. 1979. Intensive culture of Indian major carps. In Advances in Aquaculture (Ed.By Pillay, T.V.R., 1993 and Dill, W.A., 1999). Fishing New Books, Oxford. pp. 153-157.

Das, P. 1993. Fish habitat degradation necessitating conservation. Environmental Series, 4:85-89.

DOF, 2010. Sharonika, Madsha Saptah-2012. Department of Fisheries, Ministry of Fisheriesand Livestock, Government of Peoples Republic of Bangladesh. $38 \mathrm{pp}$.

DOF, 2012. Sharonika, Madsha Saptah-2012. Department of Fisheries, Ministry of Fisheriesand Livestock, Government of Peoples Republic of Bangladesh. $13 \mathrm{pp}$.

Eknath, A.E. and Doyle, R.W. 1990. Effective population size and rate of inbreeding in aquaculture of Indian major carps. Aquaculture, 85: 293-305.

Fagbenro, O.A., Salami , A. A. and Sydenham, D.H.J. 1991. Inducd ovulation and spawning in the catfish, Clarias isheriensis using pituitary extracts from non piscine sources. J. Appl. Aquacult., 1(4): 15-20. 
FAO, 1983.Fish feed technology. Rome, FAO, ADCP/REP/80/11/. $395 \mathrm{pp}$

Fermin, A.C.1986a. Principles of induced spawning. 13p. Lecture paper presented during the International training on freshwater aquaculture; 1986 September 15-October 17;SEAFDEC Binangonan Freshwater Station; Binangonan, Rizal, Philippines.

Goel, P.K. 2009. Water pollution causes effects and control. New Delhi: New age international publishers.

Hogendoorn, N. 1981. Controlled propagation of the African Catfish, Clarias lazera (C\&V) IV. Ffects of feeding regime in fingerlings culture. Aquaculture, 4:123-131.

Haque, M.M. 1991. Improved fish culture management practices for fisheries extension officers. Report on brood fish and carp hatchery management, trainers training manual. BFRI, Mymensingh. pp. 76-94.

Islam, M.N., Chawdhury, M.F.R., and Mohsin, A.B.M. 2002. Role of hatchery in the fish culture development of Rajshahi district in Bangladesh. J. Zool. Rajshahi Univ. Vol. 21, 2002. pp. 7-76.

Kumar, D. 1992. Fish Culture in Undrainable Ponds: A Manual For Extension. FAO Fisheries Technical Paper 325. Food and Agriculture Organization of the United Nations.

Mazid, M. A. 1992. Manual on fish polyculture in pond. BFRI, Mymensingh, $150 \mathrm{pp}$.

Pillay, T.V.R. 1993. The sole of aquaculture in fisheries development and management, J. fish. Res. Board. Can., 30(12): $12-17$.

Sarder, A.S., Azam, M.R. and Hossain, M.A. 2002. Private hatchery owners' perspectives on hatchery management in Bangladesh. 78 pp. In: Penman, D.J., Hussain, M.G., McAndrew, B.J. and Mazid, M.A. (eds.). Proceedings of a workshop on Genetic Management and Improvement Strategies for Exotic Carps in Asia, 12-14 February 2002, Dhaka, Bangladesh. Bangladesh Fisheries Research Institute, Mymensingh, Bangladesh.

Shaha, B.K. and Shah, M.S. 2010. Fertilization and feeding regimes in brood ponds of Indian Major Carps in Jessore and Mymensingh regions of Bangladesh. marine.res.aqua. 1(1):1-4.

Siriwardena, S.N. 2007. Freshwater fish seed resources and supply: Asia regional synthesis, pp. 59-90. In: M.G. Bondad-Reantaso (ed.). Assessment of freshwater fish seed resources for sustainable aquaculture. FAO Fisheries Technical Paper. No. 501. Rome, FAO. 2007. 628p. 